DEPARTMENT OF THE INTERIOR

U.S. GEOLOGICAL SURVEY

\title{
GEOLOGIC MAP OF THE BAYAN OBO AREA, INNER MONGOLIA, CHINA
}

By Lawrence J. Drew and Meng Qingrum

\author{
Prepared in cooperation with the \\ GEOLOGIC RESEARCH ACADEMY \\ of the \\ MINISTRY OF METALLURGICAL INDUSTRIES
}

